\title{
Digital Literatures Circulating in Spanish: The Emergence of a Field
}

\begin{abstract}
The launching of Google Books and of Google Earth in 2004 could be considered a symbolic landmark for building memories. In this context, we consider that digital literatures are a very useful workbench for exploring the consequences of global digital circulation as a factual process but also as an imaginary storytelling. Literatures born digital can show how rituals of reading, formulas of production, and narratives are being modified in the twenty-first century. This article traverses a very large and diverse domain: digital literatures circulating in Spanish all over the world, not just those created in Spanish-speaking countries. The starting point is Ciberia, a repository of digital literature in Spanish, but other digital collections such as LitElat, IloveE-Poetry, Hermeneia, ELMCIP, and ELO are also covered. The authors use a post-Bourdieu methodology to study circulating digital literatures in Spanish as an emerging and dynamic field. By doing so, they show how these literatures give birth to new communities of reader-writers, reading differently and perhaps announcing how readers from the new generation are going to read.
\end{abstract}

Keywords: digital literatures, globalization, literary field

Why do we talk about digital literatures? Moreover, why do we talk about literatures at all? Given that literature no longer ranks first among cultural values, and the things that matter seem to be happening elsewhere, in the multiple regions of the multimedia universe, can electronic devices be faulted as culprits for the crisis in reading?

Quite the contrary, in our view: since, nowadays, the experimental space for forms and representations is online, on the Internet, we need to turn our analytical lens to digital literature. By digital literature, also known in the Anglo-Saxon world as electronic literature, we mean a form of art that fuses literary and technological experimentation to form a new category of texts, texts that can no longer be printed without a major degradation in their structure and performance. These types of works have the Internet as their natural habitat, though not exclusively, since they can also be found in art galleries, exhibition halls, and performance spaces. "Digital literature" is an umbrella term that serves to contain a myriad of 
different works: hypertextual narratives, interactive fiction, kinetic and generative poetry, and so on. Despite their differences, they share an interest in exploring literary horizons broadened by electronic textualities and the global space they have helped to weave: the Internet.

First, we would like to examine this new space (a global, or, as we like to call it, hypercolonial one [Sanz 2013]), for in it we witness the emergence of a field of literary and artistic innovation that can serve as a laboratory for studying new relations with global discourses and collective imaginations. Second, we would like to observe how the Spanish field develops and positions itself within the arena of digital literatures circulating in this global network, as opposed to other forms of the institutionalization and construction of literary fields at other moments or in other locations. And finally, in the works of digital literature analysed, we would like to trace whether this global network has also triggered the formation of other imagined communities, of a worldwide imagination, a global memory.

The questions are the following: has a digital literature field emerged? Is it emerging in Spanish? What position do digital literatures in Spanish occupy in the framework of global circulation? Are digital literatures contributing to building a global collective imagination in a specific way?

As a starting point, we might agree that the twenty-first century would like to consider itself global. After 2004, when techniques of storing, transferring, and processing information (Google Books), techniques of geolocation linked to an acceleration of transportation (Google Earth), and technologies of socialization (Facebook) emerged as dominant phenomena, the First World seemed to ignore the frontier and instead preferred jet-lag. Whereas Don Quixote measured distances in leagues (never in hours or minutes), we measure them in numbers of hours, not in kilometres. Although school geography has contributed to (re)producing territorial identity in a number of countries, the world map, with its deformations resulting from the move from round to flat, is no longer our representation of the world; the one provided by Google Maps, however, is.

Digital literatures are a real asset when we want to deal with major issues such as the globalization of literature: they circulate throughout the Web, they cannot be encased in national boundaries, and they address the anxieties of a shared culture: digital culture. But this digital culture that spreads though the Internet is neither unique nor monolithic, neither global nor local; it speaks English but also many other languages that are progressively colonizing what was once a predominantly US territory. More precisely, digital literatures could be considered laboratories where we can study the way reality appears to us on our screens; these narratives propose a "space of possibilities" for our cultural history.

Thus, our main contention is that the study of digital literature can help us explore anew the way literatures are born, how they circulate and travel, and how 
they address audiences and form communities of readers around them. They can also help us visualize, and therefore deal with, the problems lurking in the process of globalization that is taking place.

Beyond the national context, in which literature was used as the base of "political reasoning," digital literary objects can represent other forms of belief in a community: other imagined (and imaginary) communities, other "cultural artifacts" (Anderson 1986). They could form a global narrative that functions not like a supraculture but like an instance of cultural friction (Tsing 2005). More than ever, we should pay attention to this kind of phenomenon: if the nation state had to assert itself over the polyphony of the nation, electronic literary spaces should be able to assert their polyphonies over globalization and the imposition of any monoculture. Or, at least, we should consider this as a possibility: that is what we advocate.

In this article, we will explore the strategies employed by artists to endow their works with a global scope, and their attempts at making the frictions in the globalization of literature visible, as well as their answers to the forces at work in a global network dominated by technopower. We will also present an overview of this nascent field by describing the coalescence of a community of readers around institutions and organizations dedicated to the study of digital literature in Spanish. Examples of digital literature in Spanish from our digital repository Ciberia (http://repositorios.fdi.ucm.es/CIBERIA) will foreground the frictions and clashes that form the basis of our quotidian practices of globalization. ${ }^{1}$

Let us discuss, then, three aspects that make digital literature, and digital literature in Spanish in particular, a productive case study: (a) its form of circulation in a global network, $(b)$ its disruption of national boundaries, and $(c)$ its metaliterary reflections regarding its own essence and medium: electronic textuality.

First, digital literatures are born to circulate on the Internet, in several languages or heavily reliant on English, in translation or defiantly untranslatable. Moreover, works of digital literature converge around themes and forms of edition that also reflect upon their own privileged medium of dissemination: the Web. Dealing with digital literatures, the crucial question is less "where do you come from?" and more "what places did you traverse to get here?" and "where are you going?" because circulation is meaningful, just as origins are.

The crucial question is: does it make sense to talk about digital literature in terms of language of production, which "merely" describes the content but is no

1 Ciberia: The Library of Electronic Literature in Spanish (http://repositorios.fdi.ucm.es/CIBER IA) is a repository run by the LEETHI research group from the Complutense University of Madrid and headed by María Goicoechea and Laura Sánchez. 
longer as relevant as the form? Can we talk about a community of readers where the Spanish language is concerned? The problem with Spanish, as well as other transnational languages described as linguistic communities, is that it encompasses many different types of Spanish belonging to diverse cultural areas. We cannot, as we can see in Ricardo Iglesias's Koinonía, ${ }^{2}$ consider a single IberoAmerican space. One might be tempted to speak about a digital literature from capitals, but in that case the plural (capital-s) would have to be emphasized: Madrid-Barcelona-Buenos Aires-Bogotá-Mexico-Los Angeles-Miami-San JuanSantiago ....

Second, digital literatures cannot be encased in national boundaries, and even less so in state or territorial boundaries. There are several arguments in support of this view. The national origins of creators are often uncertain because they belong to the Hispanic diaspora for political, economic, or intellectual reasons; and technological (global) skills (cybercultural ones) are required, since users have to activate a bundle of collective memories and competencies when exploring a digital work. Consequently, no national archives exist for this "patrimony"; 3 nevertheless, you will find collections of digital literatures in repositories such as ELO, CELL, ELMCIP, Hermeneia, or our Ciberia, ${ }^{4}$ which welcome materials from all sides. In fact, we could use digital literatures as a global allegory for this "hypercolonial" function, since we have not managed to find works dedicated to the exaltation of origins - quite the contrary.

In the Spanish-speaking context, we also find a proliferation of platforms dedicated to e-lit creations linked to a particular region: Cultura digital de Chile, or CCD, or - for Latin-American works and authors - LitElat. ${ }^{5}$ This could be an example of how the Spanish-speaking context works as a multicentred field: perhaps we can talk not of a centralized network, or of a distributive one, but of a decentralized network (Ugarte 2007). But why do we have so many repositories in

2 Koinonía (Iglesias 2007) uses an interactive web in which we are allowed to play with the meaning of words, constructing expressions with Mexicanisms. It is interesting to note how this work, so concrete in a cultural or linguistic respect, acquires new meanings by being available online and collected in several repositories of digital literature in Spanish.

3 A meaningful exception, reflecting the important German investments in the digital humanities domain, is Literatur im Netz (2016).

4 The Electronic Literature Organization (http://eliterature.org/) and its Consortium of Digital Literature (http://eliterature.org/cell/), Electronic Literature as a Model of Creativity and Innovation in Practice (https://elmcip.net/), Estudis literaris i tecnologia digital: Hermeneia (http:// www.hermeneia.net/), or our Ciberia (http://repositorios.fdi.ucm.es/CIBERIA).

5 Cultura digital de Chile (http://culturadigitalchile.cl/literatura-obras/), Centro de Cultura Digital de México (http://www.centroculturadigital.mx/), or LiteLat: Red de Literatura Electrónica Latinoamericana (http://litelat.net/). 
Spanish based on regions of production, if this production of e-lit is intended to be transnational? There is no doubt that the Spanish from Spain can be perceived as a colonial imposition and the pluralistic Spanish-speaking world rebels against this.

The Ciberia repository is one example that deals with this problem: the aim of this repository is to classify digital literatures in Spanish, wherever they come from. In a digital context without borders, Spanish is the new "virtual nationality." The sixty-three works of Spanish e-lit included in the repository have been produced by authors belonging to eight nationalities, but these nationalities are not tagged or searchable (only five Spanish-speaking nationalities are included in the third volume of the ELO collection). ${ }^{6}$

Some more specific examples may support our thesis regarding the disruption of national boundaries implied in many works of digital literature. Buenos Aires Word (Pintabona 2005) is an online word processor, and even if it plays with images of public spaces in the city of Buenos Aires, the result is a familiar setting, with common images that we all recognize and which could be in any city in the world; it is the global imagination of urban space, with its graffiti and neon lights. This is a clear example of how even the local collective image ends up being decentred after multiple journeys (virtual, imaginary ones) and becomes unable to link itself to any concrete origin. Something similar occurs in Our Dreams Are a Second Life, a work by Belén Gache (2012) in which the avatar of the author moves through virtual space (Second Life) reciting Nerval.

Third, digital literatures are cultural practices that are oriented towards the exploration of the new expressive possibilities brought about by the electronic medium, very much like a neo-avant-garde movement, and are concerned with subverting the print medium. We should note that digital or electronic literatures exclude much of the literary content that is consumed daily on digital devices, which could be printed out without any fundamental loss because it is merely a transcription of the print paradigm. Digital creations have an essential characteristic: that of proposing reflections on current transformations of the literary field that deserve to be followed. For instance, they have a strong metaliterary component that particularly interests us. This is the case with "Escribe tu propio Quijote" [Write Your Own Quixote] (one of the Wordtoys of Gache [1996-2006]): it is a work that does not seem to age, precisely because it resorts to technology in a metatechnological way, wondering about the identity of the text and of its cultural and literary pillars, such as Don Quixote. Starting with the premise "We are all Rembrandt, we are all Cervantes" (our translation), Gache places the reader in the

6 Electronic Literature Collection. Vol. 3. http://collection.eliterature.org/3/ (10 February 2018). 
position of the writer facing the blank page of a word processor, only to discover after moments of hesitation that typing on the keyboard will inevitably make Cervantes's text resurface on the screen. Precisely because these works tend to function as metaliterary practices and their core questions are mainly aesthetic and literary, they are able to cross over political frontiers to install themselves in their own "literary nation" (Romero 2006).

In fact, digital literatures want to appear global. We have identified several strategies that they employ in order to do so (Llamas 2015; Sanz 2017). The first consists of overcoming the problems of understanding that are entailed by linguistic differences and the lack of knowledge of a linguistic code, for example by using a unique linguistic code that is understood as already globalized through its globalized use in other frameworks like that of the international market. Examples can be found in the English titles used for works written in other languages, such as Wordtoys by Belén Gache (1996-2006). A text in English often lives sideby-side, as a translated version, with other versions in different languages, for example Condiciones extremas/Extreme Conditions by Juan B. Gutiérrez (19982006). ${ }^{7}$ But one can also try to overcome these problems of understanding by replacing the linguistic code with a visual and sound code, such as concrete poetry or avant-garde visual poetry. The problem posed, then, is that, in order to reach a global public without the restrictions imposed by languages, one sacrifices transmission of a work's linguistic semantic significance, as explained by SchmitzEmans (2000, 294).

The second strategy consists of the use of the technological medium itself; its basis and computer codes are already global and function as part of the artistic literary creation. The most successful forms of practical software use in daily life to have emerged with this technological code have also inspired the appearance of practices and rituals that belong to a new global cultural order. But this order, in spite of its appearance of neutrality and universality, circulates all over the world from certain maxims and positions created in the West. Specifically for this reason, some creators underline its character as discursive, as organizing and structuring collective knowledge. Precisely this technological code, which overcomes linguistic barriers and is present in all the works of digital literature, is shown by some authors to be insufficient without other languages and natural languages, as in Eidola Kosmos by Isaías Herrero Florensa (2008), for example.

These globalized rituals also occur on the reading level and are different from the ones that occurred with paper. The need to interact physically with the elec-

7 The first version is in Spanish from 1998, and the third version is in Spanish and in English and is from 2006. 
tronic device generates a new performance of reading, for example using the mouse to continue reading or with new gestures in a haptic sense. In Más respeto que soy tu madre by Hernán Casciari (2003), presented as a real blog written by Mirta Bertotti, for example, the form of the weblog itself is part of globalized knowledge, but has elements of variability and is anchored in its original aesthetic configuration. Furthermore, the global order is heterogeneous and, even if everyone performs the same action (answering a mobile phone, for example), that action does not necessarily have the same meaning in each case; the practice causes friction in each specific situation.

Finally, we find a broad range of formulas that allow for the globalization of one's own individual or collective experience through friction with globalized discourse. Thus, a text element that refers back to something concrete and recognizable is associated with collective images that have already been globalized, such as that of popular audio-visual culture in Memory by Pedro Valle Javier (2013). Or it can happen that the work in itself represents a global and transcultural network and that microintersections can be visible inside it, as in Diorama by Moebio (2004). These formulae both update the global discourse and react to limits of, or reflect critically on, globalization.

All in all, digital literatures enable us to observe phenomena not on a national scale, but from a "promontory" where boundaries fade but circulation becomes observable, in such a way that some other new questions appear: since these literatures circulate freely, and in most cases for free on the Internet, would they have a place in a symbolic, cultural "market"? What happens when the specific shared meeting places are located on the Internet and not in a central, preeminent, national cultural site? Would this universe constitute its own capital, its provinces and its limits, and which languages would become instruments of power?

Indeed, one might think that these artificially made multimedia products, destined for the widest dissemination thanks to free circulation on the Internet, could achieve success as mass literature, but this is not the case: since the criteria and recipes of digital literatures are not tested, as is the case with old, established commercial literature, these literatures become a laboratory occupied by the happy few who nevertheless communicate amongst themselves, create links and networks, and finally get organized.

In fact, there are two opposing poles in the digital literature field: technology on the one hand, institutionalization on the other. Indeed, it is the meridian of hitech Silicon Valley that measures aesthetic distance and institutes the present. This amounts to saying that modernity in digital literature is decreed by the technological meridian, and anachronisms would be typical of digital literary spaces far from Silicon Valley. Time serves to measure the digital divide that comes with 
it, and that is the norm nowadays. In the "Digital Republic," the best-endowed spaces are also the oldest (the ones that first entered technological competition), in such a way that the only path for digital literatures to become "global," even "universal," seems to be through "denationalization" and through a kind of hypercolonial westernization. But at the same time, the institutionalization process is currently so strong that this pole of attraction becomes more and more active.

It is a fact that the field of digital literature does not yet have a developing economic market, apart from a few more or less successful attempts: Apple has, through its Apple Store, supplied the platform used to launch some works of digital literature aimed at children; ${ }^{8}$ and Eastgate Systems (http://www.eastgate. $\mathrm{com} /$ ) has been selling digital literature "classics," first on CD-ROM and now using pendrives, since 1982. But we can say that digital literature's cultural capital operates as a matter of status: as symbolic capital. The point is that Anglo-Saxon research teams, who became interested in the digital literature field a long time ago, have filled the academic market with creative and critical works in English. English prevails in associations such as ELO, meetings such as those of E-Poetry or ELO, consortia such as CELL, or even some European projects such as ELMCIP, which we presented above.

We could mention, for example, some problems we had integrating Ciberia entries into CELL, a consortium of electronic literature repositories, where, even though its search engine standardizes categories of classification, English prevails - so much so that we had to translate and adapt the categories of Ciberia to enable the interoperability and exporting of our data. Although CELL claims it makes an effort to reach a common standard of consensual terms that serve to define the field of digital literature, the truth is that the members of the consortium use English not only in their discussions but also to program the database, which increases the difficulty of integration for non-English databases, in spite of the fact that the terminology for categories, tags, and metadata has been chosen by consensus and the members of the consortium have been working and making decisions together.

But in the end, Ciberia forms part of CELL, and to a certain extent it has been able to participate in the construction of this standard; thus, the whole collection of works we have gathered in Ciberia shows that, in the field of the digital environment, not only does the literary and intellectual map not match the political map: it does not match the technological map, or the economic and social one,

8 Such as Árbol con patas or Haiku-mático by José Alfonso Ochoa, two beautifully designed pieces sponsored by CONACULTA (the Mexican National Council for Culture and the Arts). 
either. This conscious integration of works into academic repositories is a polyphonic answer to an otherness perceived as hypercolonial and threatening.

To counter this hegemony, we need another metaphor for the digital literature field; the metaphor of the playing field, which suggests the role of subjective perceptions and strategic action. Indeed, subjects as actors are significant because their resistance and protests permanently shape the dynamics of innovation. Actors have to place their works in the arena and to have something to say: Jean Pierre Balpe (2013) in France or Pedro Barbosa in Portugal claimed, avant la lettre, the term "écrilecture" or "escrileitura" as their own before the extension of, or at least in parallel to, the use of "wreader" by North American critics; ${ }^{9}$ Claudia Kozak claimed the tecnopoéticas ou poétiques politiques for Argentina, Brazil, and Latin America in general (Kozak 2012); and Serge Bouchardon (2014) defended his double identity as creator and critic.

Indeed, there is a sense of social responsibility that has become a major trait of digital literatures in Latin America. Digital literatures are considered actions, more practical than discursive, embodied as well as cognitive, durable though adaptable, reproductive though generative. This is the case with IP Poetry by Gustavo Romano (2006): metatechnological, metalinguistic, metaliterary.

Perhaps, looking from the Silicon Valley meridian, these experiences could be considered as less innovative technologies, or as part of "low tech" (secondhand, outdated technology) or "soft tech" (a term that we prefer in order to define extremely simple programs available to anybody). ${ }^{10}$ But this is not an act of technological resignation. On the contrary, it is a genuine strategy of creation, a kind of epistemological sovereignty, like an anthropocentric answer to the technocentric invasion.

\section{Works cited}

Anderson, Benedict. Imagined Communities: Reflections on the Origin and Spread of Nationalism. London: Verso, 1986.

Balpe, Jean-Pierre. e.littérature. 2013. http://articlesdejpbalpe.blogspot.fr/ (18 February 2018). Bolter, J. David. Writing Space: The Computer, Hypertext, and the History of Writing. Hillsdale: Erlbaum, 1991.

9 See Torres (2004, 145n1).

10 We could take as an example above all May Yoctobit's Homeward Journeys (2011), which have a minor level of investment and technical development but are works created (1) from a collective authorship (and this is very important because there are not many authors who sign collectively above all in digital literature) and (2) against a background of social exploration and technology citizenship (Medialab). 
Bouchardon, Serge. La Valeur heuristique de la littérature numérique. Paris: Hermann, 2014. Casciari, Hernán. Más respeto que soy tu madre. 2003. http://mujergorda.bitacoras.com/ (22 July 2016).

Gache, Belén, Wordtoys. 1996-2006. http://www.findelmundo.com.ar/wordtoys/index.htm (10 February 2018).

Gache, Belén. Our Dreams Are a Second Life. 2012. http://repositorios.fdi.ucm.es/ciberia_oda/ view/cm_view_virtual_object.php?idov=395\&seleccion=1 (10 February 2018).

Gutiérrez, Juan B. Condiciones extremas/Extreme Conditions. 1998-2006. http://www.literatronica.com/src/Nuntius.aspx?lng=BRITANNIA\&opus=1\&pagina=\&nuntius=OPUS_ABOUT_1\&artifex= (10 February 2018).

Herrero Florensa, Isaías. Eidola Kosmos. 2008. http://www.elevenkosmos.net/ek/ (10 February 2018).

Iglesias, Ricardo. Koinonía: Máquina de palabras. 2007. http://www.ricardoiglesias.net/2010/ 12/koinonia-maquina-de-palabras-2007/ (10 February 2018).

Kozak, Claudia. Tecnopoéticas Argentinas: Archivo blando de arte y tecnología. Buenos Aires: Caja Negra, 2012.

Literatur im Netz. Deutsches Literaturarchiv Marbach, 2016. http://literatur-im-netz.dla-marbach.de/ (10 February 2018).

Llamas Ubieto, Miriam. "Digitising the World: Globalisation and Digital Literature." Neohelicon 42.1 (2015): 227-251.

Moebio [Ortiz, Santiago]. Diorama. 2004. http://moebio.com/santiago/diorama/ (10 February 2018).

Pintabona, Juan. Buenos Aires Word. 2005. http://repositorios.fdi.ucm.es/ciberia_oda/view/ cm_view_virtual_object.php?idov=337\&seleccion=1 (10 February 2018).

Romano, Gustavo. IP Poetry. 2006. http://ip-poetry.findelmundo.com.ar (10 February 2018). Romero, Dolores. Naciones literarias. Barcelona: Anthropos, 2006.

Sanz, Amelia. "Digital Humanities or Hypercolonial Studies?" RICT, Responsible Innovation, Ethical Issues. 2013. https://www.orbit-rri.org/concepts/digital-humanities-or-hypercolonial-studies/ (30 March 2015).

Sanz, Amelia. "Digital Literatures Circulation: Testing Post-Bourdieu Theories." Reading Wide, Writing Wide in the Digital Age. Spec. issue of Neohelicon 44:1 (2017): 15-25.

Schmitz-Emans, Monika. “Globalisierung im Spiegel literarischer Reaktionen und Prozesse." Literatur im Zeitalter der Globalisierung. Ed. Manfred Schmeling, Schmitz-Emans, and Kerst Walstra Würzburg: Königshausen \& Neumann, 2000. 285-315.

Torres, Rui. “Digital Poetry and Collaborative Wreadings of Literary Texts.” Telepoesis. 2004. http://www.telepoesis.net/papers/dpoetry.pdf (18 February 2018).

Tsing, Anne Lowenhaupt. Friction: An Ethnography of Global Connection. Princeton: Princeton University Press, 2005.

Ugarte, David de. El poder de las redes: Manual ilustrado para personas, colectivos y empresas abocadas al ciberactivismo. Barcelona: El Cobre, 2007.

Valle Javier, Pedro. “Memory.” Synesthesia. 2013. http://synesthesiasinestesia.blogspot.no/ 2013/04/memory-e-poetry.html (10 February 2018)

Yoctobit, May. Homeward Journeys. 2011. https://yoctobit.wordpress.com/category/homewardjourneys (21 March 2019). 
María Goicoechea, Miriam Llamas, Laura Sánchez, and Amelia Sanz belong to LEETHI (European Literatures from Text to Hypermedia), an interdisciplinary research group born in 2000 at the Complutense University of Madrid. Their research activity focuses on the transformation of literary communication due to digital technology and globalization. 
